\title{
RETROSPECTIVE STUDY OF PATIENTS WITH CHIARI MALFORMATION SUBMITTED TO SURGICAL TREATMENT
}

\author{
Mário Augusto Taricco ${ }^{7}$, Luiz Ricardo Santiago Melo ${ }^{2}$
}

\begin{abstract}
The Chiari malformation (CM) is characterized by variable herniation of one or both cerebellar tonsils, associated or not with displacement of the hindbrain structures into the vertebral canal. This is a retrospective study of 29 patients with CM submitted to surgical procedure between 1990 and 2003. There were 14 females and 15 males whose ages ranged from 16 to 65 years. There were seven patients with isolated CM, 12 associated with syringomyelia (SM), three associated with basilar impression (BI) and seven associated with $\mathrm{SM}$ and $\mathrm{BI}$. The surgery was based on posterior fossa decompression. In seven patients a catheter was introduced from the subarachnoid space into the III ventricle and five were submitted to tonsillectomy. Twenty-one patients improved, one worsened, one remained unchanged, four missed follow up and two died. We conclude that the best results with $\mathrm{CM}$ surgery are obtained by an effective posterior fossa decompression. Those CM cases associated with other abnormalities, such as SM and BI, probably need complementary techniques which will be the theme for new prospective studies.
\end{abstract}

KEY WORDS: Chiari malformation, posterior fossa, hindbrain malformations, surgical treatment.

\section{Estudo retrospectivo de pacientes com malformação de Chiari tratados cirurgicamente}

Resumo - A malformação de Chiari (MC) é o deslocamento variável de uma ou ambas as tonsilas cerebelares para o canal vertebral. Este trabalho é um estudo retrospectivo de pacientes com MC tratados com cirurgia de 1990 até 2003. Foram analisados 29 prontuários, sendo 15 pacientes do sexo masculino e 14 do feminino, com idade variando entre 16 a 65 anos. Destes, sete só apresentavam MC, 12 tinham MC associada com siringomielia (SM), três associada com impressão basilar (IB) e sete associada com SM e IB. Foi realizada descompressão da fossa posterior e plástica da dura-máter em todos. Em sete pacientes, foi acrescida a colocação de catéter do espaço subaracnóideo para o interior do IV ventrículo e em cinco a tonsilectomia. Ocorreu melhora dos sintomas em 21 pacientes, um permaneceu inalterado, houve piora em um caso, quatro não tiveram seguimento e dois faleceram. Conclui-se que a boa evolução da $M C$ está relacionada com a descompressão efetiva da fossa posterior. Os casos de MC associadas a outras malformações, como IB e SM, talvez necessitem variações técnicas, as quais serão temas de novos estudos prospectivos.

PALAVRAS-CHAVE: malformação de Chiari, fossa posterior, malformações do rombencéfalo, tratamento cirúrgico

Chiari malformation (CM) is an anomaly of the craniovertebral transition characterized by the displacement of one or both cerebellar tonsils into the vertebral canal, through the foramen magnum, with or without portions of the brainstem. It may be associated with other changes such as syringomyelia (SM) and basilar invagination (BI).

In 1883, John Cleland' described deformities of the brainstem, cerebellum, spina bifida and medullary cavitations. In 1891, Chiari ${ }^{2}$ described the three first types of anomalies of the neuroaxis in the craniovertebral transition region based on a few cases and Chiari himself, in
1895 , based on a higher number of cases, described the three types and added the fourth type, thus described: Type I - displacement of the cerebellar tonsils and of the medial portions of the inferior lobes of the cerebellum, which follow the bulb in the inside of the cervical canal; Type II - displacement of the lower portions of the cerebellum, pons, medulla and part of the elongated IV ventricle inside the cervical canal; Type III - significant portions of the cerebellum and brainstem are dislocated caudally and the orifices of the IV ventricle open into the cervical canal, configuring the cervical hydrocephalus through

Spinal Group, Neurosurgery Division, Hospital das Clínicas da Faculdade de Medicina da Universidade de São Paulo, São Paulo SP, Brazil (HCFMUSP): 'Professor Responsible for the Group; ${ }^{2}$ Physician Colaborating with the Group via Post-graduation.

Received 30 August 2007, received in final form 16 January 2008. Accepted 2 February 2008. 

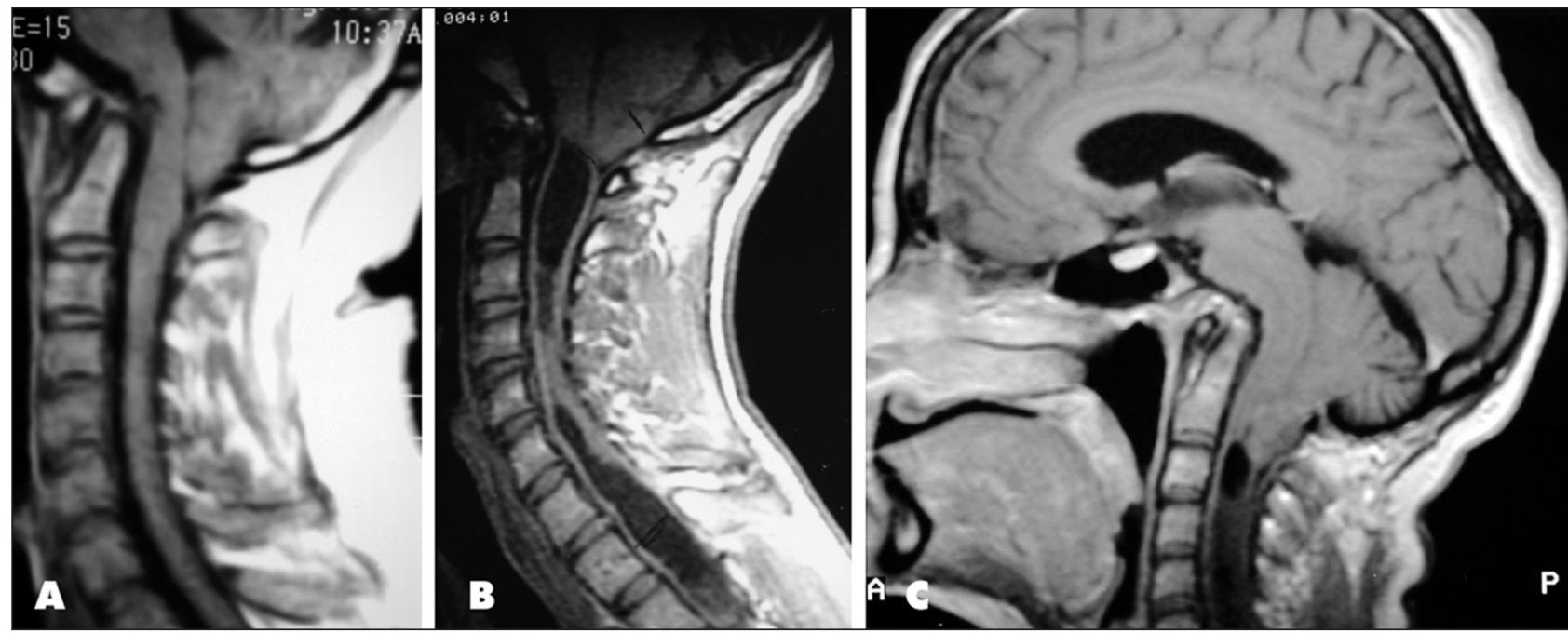

Fig 1. MRI in sagittal cuts showing the caudal displacement of the cerebellar tonsils; (A) isolated Chiari malformation; (B) Chiari malformation associated with syringomyelia; (C) Chiari malformation associated with syringomyelia and basilar invagination.

spina bifida of the three first cervical vertebrae; Type IV - hypoplasia of the cerebellum without caudal displacement of the brainstem. In 1894, Julius Arnold ${ }^{4}$, professor of pathological anatomy in Germany, described the case of a child with myelomeningocele where the cerebellar tonsils dislocated caudally until the middle portion of the cervical canal. In 1907, Schwalbe and Gredig ${ }^{5}$ proposed the eponym Arnold-Chiari malformation for the herniation of the cerebellar tonsils. However, in the opinion of other authors such as Sarnat ${ }^{6}$ and Williams ${ }^{7}$, they should be designated by the name Chiari malformation or by the expression "herniation of the cerebellar tonsils."

In Brazil, many authors, have dedicated themselves, or still do, to studying the occipitocervical malformations, such as Caetano de Barros ${ }^{8}$, Gonçalves da Silva ${ }^{9}$, Almeida $^{10}$, Rabello", Taricco ${ }^{12}$, Arruda ${ }^{13}$, Botelho ${ }^{14}$, among others.

The symptomatology may be manifested as medullary syndrome that is expressed mainly by spasticity and pyramidal signs (hyperreflexia) and consequent change of gait and sensitivity; as cerebellar syndrome by lack of balance and motor incoordination; as brainstem syndrome, characterized by dysphonia, difficulty swallowing, vertical nystagmus and dizziness. Patients may experience pain manifested by cervicalgia consequent to the herniation of the cerebellar amygdalae and that worsen with the Valsalva maneuver or by basilar invagination and osteoarticular changes in the occipitocervical region. They may also present sleep disorder characterized by sleep apnea. The diagnosis is based on clinical findings complemented with imaging tests. Among the imaging tests, magnetic resonance (MR) of the craniovertebral transition and of the cervical spine is the test that allows for a precise diagnosis and visualization of the cerebellar tonsils herniating through the foramen magnum. Magnetic resonance shows the existence of other abnormalities such as syringomyelia and/or basilar invagination (Fig 1). More recent studies allow the flow of fluid of this region to be studied. Radiographs of the craniovertebral transition show us possible bone changes of the region such as basilar invaginations, changes in the shape of the skull, besides regional instabilities (such as subluxations). Computed tomography $(\mathrm{CT})$ with the axial cuts and sagittal and coronary reconstructions supplies more details of the bone changes seen in radiographs, allowing for a better understanding of the abnormalities that are present. The neurophysiological tests such as electroneuromyography (ENMG) and evoked potential (EP) are done mainly in those cases where amyotrophic lateral sclerosis (ALS) and multiple sclerosis (MS) are suspected. Finally, polysomnography can be requested for those cases where sleep disorders are present. Surgical treatment is where the decompression of the suboccipital region is done in order to remake the cisterna magnum. Since some cases show no improvement in neurological changes after surgery, surgery is controversial, such as when and how much to decompress, which is the best surgical position, the material for the plastic surgery of the dura mater, the craniovertebral fixation and performing the cerebrospinal fluid shunt.

The objective of this study is to be able to answer some doubts on the treatment of this disease based on our experience.

\section{METHOD}

Twenty-nine medical records of patients with CM submitted to surgical treatment in the spinal group of neurosurgery of HCFMUSP from 1994 to 2003 were analyzed. All of them had the CM diagnosis confirmed by magnetic resonance (MRI) and neurological assessment immediately before and after surgery. 
Table 1. Symptomatology by pathology in 29 patients.

\begin{tabular}{lcccc}
\hline Symptomatology & CM & CM+SM & CM+BI & CM+SM+BI \\
\hline Cer. S. & 1 & - & - & - \\
Med. S. & 2 & 8 & - & 2 \\
Pain & - & - & 2 & 1 \\
Cer. S. + CN & 3 & - & - & - \\
Med. S. + CN & - & 3 & 1 & 4 \\
Cer. S. + Med. S. + CN & 1 & - & - & - \\
Cer. S. + Med. S. & - & 1 & - & - \\
\hline
\end{tabular}

Cer. S., cerebellar syndrome; Med. S., medullary syndrome; CN, cranial nerves.

Table 2. Progression by pathology in 29 patients.

\begin{tabular}{lccccc}
\hline Pathology & Improved & Unchanged & Worse & Died & Unknown \\
\hline $\mathrm{CM}$ & 7 & - & - & - & - \\
$\mathrm{CM}+\mathrm{SM}$ & 6 & 1 & 1 & - & 4 \\
$\mathrm{CM}+\mathrm{BI}$ & 3 & - & - & - & - \\
$\mathrm{CM}+\mathrm{SM}+\mathrm{BI}$ & 5 & & & 2 & - \\
\hline
\end{tabular}

$\mathrm{CM}$, Chiari malformation; SM, syringomyelia; BI, basilar invagination.

Most attended outpatient follow-up, except for four patients who did not show up for the follow-up visits and two who died. Of the 29 patients, 15 were males and 14 were females and their ages ranged from 16 to 65 years. Seven had only CM, 12 had CM associated with SM, three had CM associated with $\mathrm{BI}$ and seven had $\mathrm{CM}$ associated with $\mathrm{BI}$ and SM.

\section{RESULTS}

Regarding the neurological examination, we observed that: out of the seven patients who had only CM, one had isolated cerebellar syndrome, three had cerebellar syndrome and compromised cranial nerves, one had cerebellar syndrome, compromised cranial nerves and medullary syndrome and two had medullary syndrome. Of the 12 patients with CM associated with SM, all had medullary syndrome, one had associated cerebellar syndrome and three had compromised cranial nerves. Of the three patients with $\mathrm{CM}$ associated with $\mathrm{BI}$, all of them had medullary syndrome and one had compromised cranial nerves. Of the seven patients with CM associated with SM and $\mathrm{BI}$, one presented only pain, six had medullary syndrome and of these, four also had compromised cranial nerves (Table 1).

After surgery, the seven patients with CM alone and the three patients with $\mathrm{CM}$ associated with $\mathrm{BI}$ presented neurological improvement. Of the twelve patients with CM associated with SM, six improved, one remained unchanged, one worsened and four did not show up in the follow-up visits. Of the seven patients with $\mathrm{CM}$ associat- ed with SM and BI, five improved and two died because of infectious-clinical complications; one of them did present some improvement immediately after surgery though (Table 2).

\section{DISCUSSION}

There are many existing theories to explain herniation of the cerebellar tonsils through the occipital foramen. In 1895, when Chiari ${ }^{3}$ described and classified these malformations, he believed that the cause would be the development of hydrocephaly in the embryonic phase leading to the caudal migration of the rhomboencephalon. This theory became known as the hydrocephalic theory.

In 1935, Russel and Donald ${ }^{15}$, in necroscopic studies of ten individuals with herniation of the rhomboencephalon associated with myelomeningocele and hydrocephaly, admitted that the latter would be the consequence and not the cause of the obstruction of the flow of cerebrospinal fluid (CSF).

Since 1950, Gardner ${ }^{16}$, who studied the subject intensely, admitted that CM originated in the presence of hydrocephaly due to hydrodynamic hypertension in embryonic life and initial fetal life. This theory loses strength because most of the cases in adults are not associated with hydrocephaly.

In 1932, van Houweninge Grafdijk (apud Peach ${ }^{17}$ ), realizing the association between CM and spinal dysraphism, proposed the mechanical theory where the rhomboencephalon would be pulled in a caudal direction because the vertebral column grew faster than the spinal cord, thus leading to the migration of infratentorial structures through the occipital foramen.

In 1942, Lichtenstein ${ }^{18}$ admitted that in cases where there was occipitocervical invagination without the presence of spinal dysraphism, therefore without medullary traction, only the ascension of the occipital foramen contour would be enough to provoke the localization of cerebellar structures inside the cervical canal. Thus, a new theory was created, the theory of the small posterior fossa.

In 1949, Ricard ${ }^{19}$ admitted the existence of two forms of CM: one caused by the association with spina bifida occulta and the other one due to the elevation of the foramen edge into the interior of the posterior fossa.

In 1978, Nyland and Krogness ${ }^{20}$ reported a clinical and neuroradiological study in five patients with $\mathrm{CM}$ showing that the posterior fossa is smaller.

Knowing that in adult patients with CM the most probable cause is a small posterior fossa, the suboccipital decompression, laminectomy of the posterior arch of $\mathrm{Cl}$ and duraplasty are indicated, remaking the cisterna 

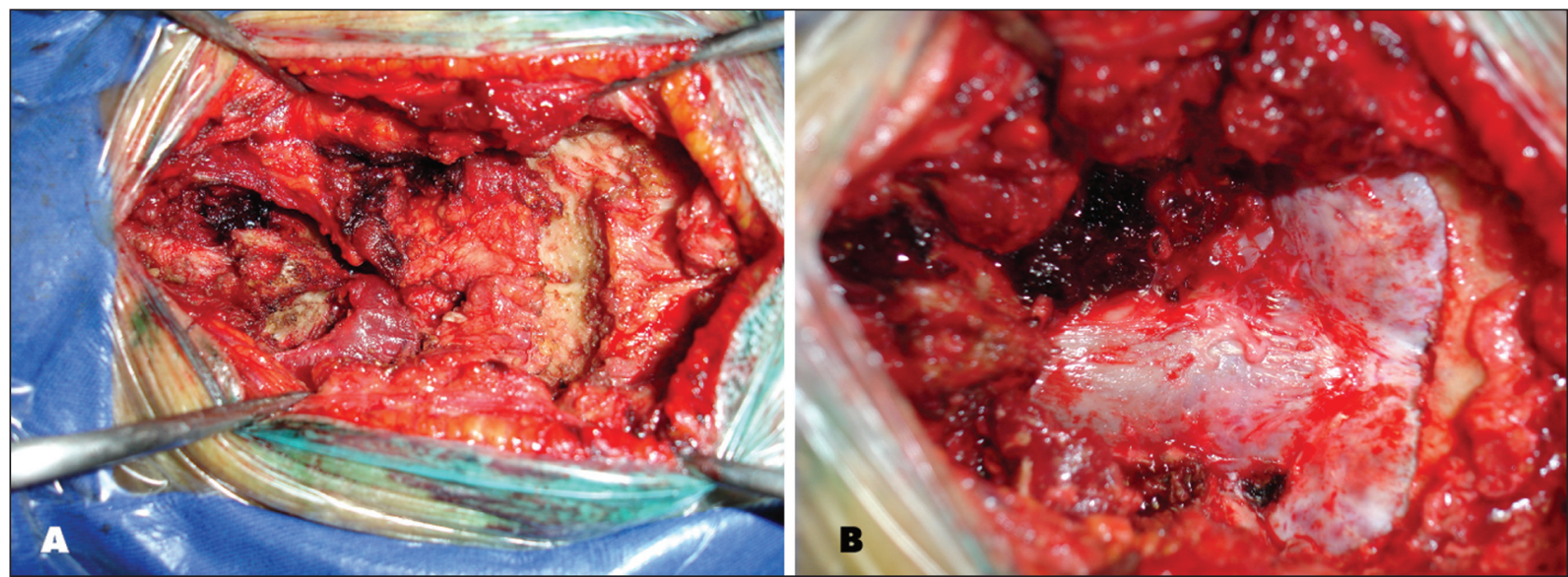

Fig 2. (A) Transoperative picture evidencing the area exposed for craniectomy; (B) Area of craniectomy and the two cerebellar hemispheres surrounded by the meninges.

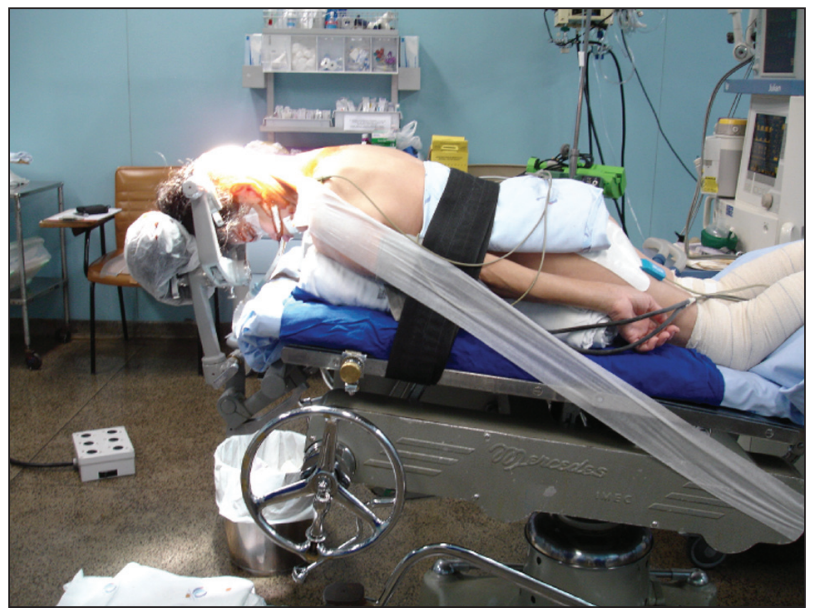

Fig 3. Prone position for surgery.

magnum and reestablishing the CSF flow. In this stage we have a controversy regarding the extension of occipital craniectomy. Large occipital craniectomies may lead to cerebellum ptosis, persistence of medullary compression and obviously no improvement for the patient. If occipital craniectomy is restricted to the periphery of the occipital foramen, it might not cause enough relief of the compressed structures in this region. To unify the procedure we adopt the occipital craniectomy with the upper limit in the insertion of the inferior inner nape muscles, extending for three centimeters on the lateral edges of the occipital foramen and on the lower side by laminectomy of the posterior arch of $\mathrm{Cl}$ and, in rare cases, laminectomy of $\mathrm{C} 2$ when necessary to reach the lower extremities of the cerebellar tonsils. We believe that in this manner, there will be enough decompression of the neurological structures in this region (Fig 2).

To reconstruct the cisterna magnum and reestablish the CSF flow, duraplasty is recommended, that is, open the dura mater and stitch it using some material placed between its edges, increasing the subdural space. This material may be the muscle fascia of the patient, which, if taken from a site other than that of the surgery may result in pain and/or another complication for the patient. We use bovine pericardium that, in our opinion, has two inconveniences. The first is that despite the fact that it is lyophilized, bovine pericardium may contain non-human protein which would lead to autoimmune reactions. Second, the fact that this product is kept in glycerin and possibly not handled correctly may lead to aseptic meningitis. New synthetic materials are becoming available but the downside is the high cost.

Still in respect to the surgical procedure, the best way to position the patient is still questioned. The sitting position makes surgery easier because bleeding and CSF outflow do not remain in the operating site whereas the same is not true for the prone position. But the sitting position may cause gaseous embolus and impairs the removal of the bone fragment, when necessary, during arthrodeses. We opt for the prone position to standardize the procedure and not have one more variable in possible future studies (Fig 3).

With the ease to diagnose $\mathrm{CM}$ with imaging tests, especially MRI, we started to provide care for oligosymptomatic patients, for example, those with pain in the cervical region or headache after physical exertion, or even to asymptomatic patients who have been submitted to imaging tests for other reasons. Would surgery be indicated in these cases? Unfortunately we do not know the natural history of this disease since most diagnosed patients have important neurological symptoms with limitations to their daily activities. In these cases our procedure is to indicate surgery only for patients with important neurological 
symptomatology or in progression and in the oligosymptomatic or asymptomatic cases we tell the patients that they should undergo periodic neurological assessment.

In our results, we found that out of the 29 patients studied and of the 25 who cam for follow-up, 21 (84\%) had improvements in their symptoms with the surgical treatment. All patients with isolated CM (seven patients) and those who had CM associated with $\mathrm{BI}$ (three patients) improved their symptoms with decompression of the posterior fossa and duraplasty. Meanwhile, the group of patients with CM associated with SM (12 patients) and those with $\mathrm{CM}$ associated with $\mathrm{BI}$ and SM (seven patients) not all patients improved. The small number of cases does not allow a statistical analysis but by analyzing these data we realize that the prognosis of CM associated with SM with or without $\mathrm{BI}$ is not as favorable as that for cases of isolated $\mathrm{CM}$ or $\mathrm{CM}$ associated with $\mathrm{BI}$.

This study motivates us to perform a prospective study that may provide better data to standardize the therapeutic procedure for patients with this disease, isolated CM or associated with other malformations such as $\mathrm{SM}$ and $\mathrm{BI}$.

\section{REFERENCES}

1. Cleland J. Contributions to the study of spina bifida, encephalocele and anencephalus. J Anat Physyol 1883;17:253-297.

2. Chiari H. Über Verränderungen dês Klainhirns infolge von Hydrocephalie dês Grosshirns. Deutsch Med Wochenschr, 1991.

3. Chiari H. Über Verränderrungen dês Klainhirns, dês Pons und Medulla Oblongata in Folge Von congenitaler Hydrocephalie dês Grosshirns. Deutsch Akd Wissenschaft, 1865;63:71-85.
4. Arnold J. Myelocyst transportation Von Gewebskeimen und Sympodie. Beitr Path Anat Allgem Path 1994;37:1-28.

5. Schwalbe E, Gredig M. Über Entwicklunsströrungen dês Kleinhirns, Hirnstammes und bei Spina bífida (Arnold'sche Missbildung). Beitr Path Anat Path 1907;71-85.

6. Sarnat HB. Embyology and dysgenesis of the posterior fossa, in syringomyelia. In Batzdorf U (Ed). Currents concepts in diagnosis and treatment. Baltmore 1991.

7. Williams B. Pathogenesis of syringomyelia. In Batzdorf U (Ed). Syringomyelia: currents concepts in diagnosis and treatment. Baltmore, 1991.

8. Caetano de Barros M, Farias W, Ataíde L, Lins S. Basilar impression and Arnold-Chiari malformation: a study of 66 cases. J Neurol Neurosurg Psychiatry 1968;31:596-605.

9. da Silva JAG, Cantisani JUF, Brito JFC, et al. Impressão basilar, ArnoldChiari e siringomielia: análise de 20 casos operados. Arq Bras Neurocirurg 1987;6:77-95.

10. Almeida GM, Bianco E, Shibata MK, Manreza LA, Marchese AJT. Tratamento cirúrgico da siringomielia pela técnica de Gardner. Arq Neuropsiquiatr 1973;31:254-263.

11. Rabello JP. Contribuição ao estudo da siringomielia: a propósito de dez casos. Tese, São Paulo, 1989.

12. Taricco MA, Pereira WC. Tratamento cirúrgico da siringomielia associada à malformação e Chiari tipo I. Arq Bras Neurocirurg 1997;16:47-60.

13. Arruda JAM, Costa CMC, Tella OI Jr, Avaliação de pacientes com siringomielia associada à malformação de Chiari: proposta de um protocolo multicêntrico. J Bras Neurocir 1999;10:93-96.

14. Botelho RV, Bittencourt LR, Rotta JM, Nery LE, Tufik S. Apnéia do sono central em paciente com malformação de Chiari I e siringomielia: tratamento com cirurgia descompressiva. J Bras Neurocirurg 1998;9:111-114.

15. Russel D, Donald C. The mechanism of internal hydrocephalus in spina bífida. Brain 1935;58:203-215.

16. Gardner WJ, Goodall RJ. The surgical treatment of Arnold-Chiari malformation in adults: an explanation of its mechanism and importance of encephalography in diagnosis. J Neurosurg 1950;3:199-206.

17. Peach B. The Arnold-Chiari malformation: its morbid anatomy and histology. Thesis. Manchester,1964.

18. Lichtenstein BW. Cervical syringomyelia and syringomyelia-like states associated with Arnold-Chiari deformity and platybasia. Arch Neurol Psychiatry 1943;49:881-894.

19. Ricard A, Girard PF. Difformité D'Árnold-Chiari (A propos dune observation). Rev Neurol 1949;81:332-342.

20. Nyland H, Krogness KG. Size of posterior fossa in Chiari type I malformation in adults. Acta Neurochir 1978;40:233-242. 